AGRICULTURA FAMILIAR, COMPETITIVIDADE E ECONOMIA SOLIDÁRIA: UM ESTUDO DE CASO NA COOPERCAJU E SUA DINÂMICA NO MERCADO INTERNACIONAL

\author{
Elitânia Evangelista da Silva \\ Graduada em Tecnologia em Comércio Exterior pelo Instituto Federal de \\ Educação, Ciência e Tecnologia Do Rio Grande do Norte - IFRN \\ E-mail: elitaniaevangelista@gmail.com \\ Elisângela Cabral de Meireles
}

Graduada em Ciências Econômicas-UFRN, esp. em Economia Regional, Comércio Exterior e Globalização-UFRN, mestre em Administração (Gestão e Políticas Públicas) UFRN , Professora do IFRN (Comércio Exterior e Economia) e Professora Orientadora da Base de Pesquisa "Análise do Mercado Exportador do Rio Grande do Norte (IFRN).

E-mail- elisangela@cefetrn.br

\title{
RESUMO
}

Tendo em vista a Economia Solidária como forma de produção, consumo e distribuição de riqueza centrada na valorização do ser humano, baseada no cooperativismo, cuja finalidade é a qualidade de vida no trabalho, promoção de ações sociais e a democratização da economia, o presente estudo tem como objetivo geral analisar a Agricultura Familiar e a Economia Solidária como fator de competitividade na Cooperativa de Beneficiamento Artesanal de Castanha de caju do Rio Grande do Norte (COOPERCAJU) e sua dinâmica no mercado internacional. Quanto a metodologia o estudo se configura como pesquisa exploratória- descritiva, com caráter qualitativo e quantitativo. Para tanto, foi realizado um estudo de caso na COOPERCAJU pela entrevista e aplicação de questionários, estruturado e não-estruturado, junto à gestora da cooperativa, que contribuiu de forma satisfatória aos questionamentos relacionados à cooperativa e os associados, objetivando responder à problemática em questão, no estudo. Os resultados obtidos demonstraram que a Economia Solidária se mostra pertinente na cooperativa, cujo principal produto comercializado, a castanha orgânica, é totalmente inserido no comércio justo (Fair Trade) e solidário, onde as ações da Economia Solidária se mostraram como fator determinante para a competitividade da amêndoa de castanha de caju no mercado internacional, bem como para $o$ desenvolvimento social e a qualidade de vida da comunidade inserida no processo.

PALAVRAS-CHAVE: Economia Solidária. Competitividade. Cooperativa.

\begin{abstract}
In view of the Solidarity Economy as a means of production, consumption and wealth distribution centered on the value of human beings, based on the cooperative movement, whose purpose is the quality of work life, promotion of social actions and the democratization of the economy, this study has aimed at analyzing the Solidarity Economy and Family Farming as a factor of competitiveness in the Cooperative Artisanal Processing Cashew Rio Grande do Norte (Coopercaju) and its dynamics in the international market. As the methodology the study is configured as exploratory, descriptive, qualitative and quantitative. For this, we performed a case study in
\end{abstract}


Coopercaju the interview and questionnaires, structured and unstructured, with the manager of the cooperative, which contributed satisfactorily to the questions related to cooperative members, aiming to answer the questions at issue in the study. The results showed that the Solidarity Economy appears relevant in the cooperative, whose main product sold, the brown organic, it is fully inserted into the fair trade (Fair Trade) and solidarity, where the actions of Solidarity Economy is shown as a determinant for the competitiveness almond cashew nuts in the international market as well as social development and quality of community life within the process.

KEY-WORDS: Economic Solidarity. Competitiveness. Cooperative. 


\section{AGRICULTURA FAMILIAR, COMPETITIVIDADE E ECONOMIA SOLIDÁRIA: UM ESTUDO DE CASO NA COOPERCAJU E SUA DINÂMICA NO MERCADO INTERNACIONAL}

\section{INTRODUÇÃO}

A globalização está promovendo grandes transformações no cenário econômico, o mundo está vivenciando muitas mudanças no mercado de trabalho, cada dia mais exigente e seletivo, com isso a sociedade menos favorecida vem buscando alternativas para garantir o desenvolvimento sustentável através da Economia Solidária.

Nos últimos anos, a Economia solidária tem sido bastante discutida no mundo, e nada mais é do que uma forma de produção, consumo e distribuição de riqueza centrada na valorização do ser humano e não do capital. Tem base associativista e cooperativista, é voltada para a produção, consumo e comercialização de bens e serviços cuja finalidade é a qualidade de vida no trabalho, promoção de ações sociais e a democratização da economia.

Os principais adeptos a essa nova alternativa, na maioria dos casos, são pequenos produtores, que estão buscando se manter no mercado, associados em cooperativas, promovendo a inserção dos produtos provenientes da agricultura familiar no mercado internacional pelo comércio justo e solidário, que tem se configurado como fator de competitividade para inserção desses produtos no comércio exterior.

Atualmente, o Brasil vem consolidando sua posição como um dos maiores produtores e fornecedores de alimento no mundo. A atuação crescente do agronegócio brasileiro no comércio internacional é resultado de uma combinação de diversos fatores, tais como, investimento em tecnologia e pesquisa, extensão territorial agricultável, clima propício e capacidade empreendedora. Nesse cenário, a agricultura familiar é um dos mais dinâmicos e inovadores segmentos da economia do país, adaptando-se continuamente às novas demandas dos consumidores gerando emprego e renda.

O Brasil exporta uma ampla relação de produtos para diversos países do mundo, principalmente para os países da Europa e para os Estados Unidos. Dentro desse contexto, destaca-se a região Nordeste com o cultivo da fruticultura, como exemplo de competitividade no mercado internacional.

O Nordeste brasileiro, historicamente, possui vantagens comparativas para a fruticultura em relação às demais regiões do país, devido ao clima e solo adequados, o que garante a sua liderança na produção e exportação de frutas tropicais. Nesse cenário destacam-se os Estados do Ceará, Piauí e Rio Grande do Norte, como maiores produtores e exportadores de Amêndoas de Castanha de Caju (ACC) do país.

No Rio Grande do Norte, a cajucultura está em plena expansão. Nos últimos quatro anos, a castanha vem se destacando no ranking dos produtos mais exportados do Estado. Com diversos produtos inseridos na pauta exportadora do Estado, frutas tropicais, pescado, a amêndoa de castanha de caju significa para o Rio Grande do Norte descentralização da economia, emprego e renda para centenas de famílias, que organizados em cooperativas, vêm expandindo, ao longo dos anos, a produção e customização do produto. 
Diante do exposto, levanta-se como problema de pesquisa: Quais os impactos da agricultura familiar e da economia solidária sobre a competitividade da COOPERCAJU (Serra do Mel, RN), no mercado internacional?

A problemática remete ao objetivo geral do trabalho que consiste em compreender os impactos que a Cooperativa de Beneficiamento Artesanal de Castanha de caju do Rio Grande do Norte (COOPERCAJU) vivencia diante das influências da agricultura familiar e da economia solidária na sua competitividade internacional em seu contexto produtivo-comercial.

Já os objetivos específicos são: conhecer a dinâmica produtiva-comercial da COOPERCAJU e identificar os principais aspectos norteadores para difusão da agricultura familiar e da economia solidária.

Quanto à metodologia, o estudo se configura como pesquisa exploratória- descritiva, com caráter qualitativo e quantitativo levando em consideração o fato de envolver levantamentos bibliográficos, a realização de entrevistas, por apresentar as características dos associados da COOPERCAJU, bem como quantificar os dados e as informações da coleta, além de classificar os processos dinâmicos vividos pelo grupo de cooperados.

As pesquisas quantitativas buscam investigar a realidade mediante técnicas de pesquisas que permitam a coleta de dados de forma objetiva. As principais técnicas utilizadas nesse tipo de pesquisa são: a) observação direta, sistêmica ou estruturada; b) questionário fechado ou semi-aberto e formulários; c) entrevistas diretiva, padronizada ou sistêmica (OLIVEIRA; FILGUEIRA, 2004).

Contrária à pesquisa quantitativa, que tem por objetivo a predição, a testagem de hipóteses e a generalização, a pesquisa qualitativa está interessada em compreender ou interpretar as ações dos atores sociais, onde o pesquisador precisa compreender $\mathrm{o}$ significado de suas ações, e imergir na realidade estudada para melhor compreendê-la e interpretá-la, cujas técnicas mais utilizadas nesse tipo de pesquisa são: a) observação dos participantes; b) entrevista não diretiva; c) estudo de caso; d) história de vida (OLIVEIRA; FILGUEIRA, 2004).

Para tanto, foi realizado um estudo de caso na COOPERCAJU pela entrevista e aplicação de questionários, estruturado e não-estruturado, junto à gestora da cooperativa, que contribuiu de forma satisfatória aos questionamentos relacionados à cooperativa e os associados, objetivando responder à problemática em questão, no estudo.

A relevância sobre o assunto se dá, pelo amplo debate que o mundo vem trazendo sobre a Economia Solidária, bem como suas ações sócio-econômicas desenvolvidas no âmbito do cooperativismo, onde milhares de agricultores familiares, cooperados, estão gerando economia de escala a nível local e global em condições de concorrência através do comércio social e solidário.

A inquietação sobre o tema iniciou com algumas peculiaridades que surgiram durante as pesquisas realizadas para a disciplina de projeto cujo objeto de estudo foi à amêndoa de castanha de caju destinada ao mercado internacional. 
Sendo a COOPERCAJU, grande produtora e beneficiadora de castanha de caju localizada no Rio Grande do Norte, com extrema importância econômica e social local, o presente estudo a teve como objeto de pesquisa por apresentar características peculiares e desenvolver a Economia Solidária através da agricultura familiar, oferecendo produto de qualidade e competitividade, na pauta exportadora do Estado.

O trabalho estar estruturado da seguinte forma: no primeiro capítulo, uma breve contextualização sobre o comércio exterior e o desenvolvimento econômico do Brasil, no segundo capítulo é conceituada a agricultura familiar e economia solidária no Brasil. Já no terceiro capitulo foi abordado a cajucultura no Brasil e no mundo, bem como os principais Municípios produtores de Amêndoa de Castanha de Caju (ACC) no RN, por fim, foi contemplado o objeto da pesquisa, o estudo de caso na COOPERCAJU, finalizando com as considerações finais provenientes da pesquisa, respondendo as questões levantadas na problemática do estudo.

\section{COMÉRCIO EXTERIOR E DESENVOLVIMENTO ECONÔMICO DO BRASIL}

Historicamente o ser humano satisfaz suas necessidades básicas, tais como, alimento, abrigo, pela produção desses bens necessários a vida do homem. $\mathrm{Na}$ medida em que o ser humano foi progredindo, foram surgindo novas necessidades, ampliando a variedade dos bens produzidos. Nesse cenário surge o processo da divisão do trabalho e consequentemente o acumulo de excedente da produção em relação ao auto-consumo, dando início à relação de troca. Essas trocas sofreram mudanças na linha do tempo, ultrapassaram fronteiras, surgindo assim o Comércio Internacional (MAIA, 2007).

Segundo Maia (2007, p. 2), em épocas pré-históricas, as trocas ocorriam entre habitantes da mesma tribo. Com a evolução do relacionamento humano, o campo de ação das trocas ampliou-se, sucessivamente, para as cidades, nações e, finalmente, para o mundo.

Isso indica que o comércio internacional está presente em grande parte da história da humanidade. Desde a Antiguidade as nações buscam em outras regiões o que não produzem internamente, objetivando satisfazer suas necessidades básicas.

Nessa relação de troca, o principal produto era o alimento. As nações com capacidade desfavoráveis à produção agrícola buscavam em outras nações suprimentos alimentícios, as regiões ricas e modernizadas garantiam maiores taxas de lucro em detrimento das regiões menos modernas. Essa realidade intensificou o comércio mundial, surgindo à importância económica, social e política deste seguimento, no mundo, nos últimos séculos.

A globalização dos mercados de bens, serviços e capitais, a internacionalização dos sistemas financeiros, integração regional, avanço tecnológico, eliminação das barreiras comercias, abertura econômicas dos países e conseqüentemente a mudança na cultura do consumo no mundo, são, dentre outros, alguns aspectos que vêm, ao longo dos anos, consolidando o comércio internacional. Por tanto, pode-se afirmar que atualmente não existe nação isolada economicamente. 
Carbaugh (2004, p. 6), afirma que:

Os últimos 50 anos viram o comércio mundial expandir-se mais rápido do que a produção mundial por uma margem significativa, aumentando o grau no qual as economias nacionais dependem do comércio internacional para a atividade geral. Em uma média básica anual, as exportações de commodities cresceram 6\% em termos reais no período de 1948 a 1999, comparados a um crescimento de $3,7 \%$ na produção média anual.

Os benefícios que o Comércio Exterior traz para uma nação são imensuráveis, pois essa atividade proporciona a abertura do país para o mundo, e com isso o aprimoramento das suas técnicas de produção, bem como a adequação dos seus bens e serviços a novas culturas.

As ações de importação e exportação se intensificaram no mundo devido à globalização, os avanços tecnológicos, e a necessidade de diversificar o consumo dos bens sem haver a necessidade de estoque a um custo reduzido.

O processo de globalização que o mundo vem vivenciando faz com que os mercados se tornem altamente competitivo, afetando, principalmente os pequenos produtores, com isso, as empresas estão buscando avaliar sua capacidade empreendedora, suas vantagens e limitações, considerando o aprimoramento dos seus bens e serviços para conquistar novos mercados. O setor agrícola é um grande precursor nesse aspecto, já que compõe a parte primária da economia de um país, com grande importância para a produção de alimentos, gerando emprego e renda. Principalmente nos países detentores de extensa área geográfica, terra fértil e clima favorável a produção agrícola, a exemplo, o Brasil.

O Brasil estar inserido no mercado internacional desde os primórdio da sua colonização, inicialmente com a percepção dos colonizadores em relação a fertilidade da terra, tanto, no tocante aos recursos naturais, como ao cultivo agrícola.

Conforme afirma Stedile (2005, p. 23), os colonizadores logo perceberam a grande vantagem competitiva do Brasil e o seu potencial para o cultivo tropical de produtos que até então os comerciantes buscavam em outras regiões, na Ásia ou África. Com isso o território brasileiro passou a produzir bens que a sociedade européia precisava, dando início ao cultivo da cana-de-açúcar, algodão, café, criação de gado, dentre outros.

Ainda, segundo Stedile (2005, p. 23), era praticada a monocultura, ou seja, cultivo de um único produto destinando-o à exportação. Produzindo apenas para o mercado externo, a localização das áreas de produção, situadas na costa do Nordeste brasileiro, deveria estar próxima dos portos, para diminuir os custos com transporte.

Os produtos cultivados no Brasil, no período colonial, eram basicamente produtos agrícolas, baseado na mão-de-obra escrava, e destinado ao mercado europeu, principalmente Portugal. Nesse contexto, a agricultura já era a principal fonte econômica do país.

No entanto, o esgotamento do modelo primário-exportador, provocado pelas crises econômicas, deu origem ao modelo de substituição da importação, a partir da década de 1930. Esse modelo objetivava enfrentar as dificuldades do encarecimento das importações e da diminuição das exportações por que passavam os países fornecedores 
de matéria-prima. Assim o Brasil passa a adotar uma política de substituição das importações, priorizando a fabricação dos bens que até então eram importados (SOUSA, 2009).

O modelo de substituição das importações deixou como herança uma estrutura produtiva interna pouco competitiva, desencadeando altos índices de desemprego, inflação, dentre outros males que a economia brasileira demorou para amenizá-los. Em compensação, houve mudanças no cenário internacional, além do enfoquem as políticas sociais no país.

No que diz respeito ao setor agrícola, segundo Stedile (2005 apud PRADO), a ponta de lança de todo o desenvolvimento da agricultura brasileira sempre foi a agricultura comercial em grande escala. No entanto com a crise do modelo agroexportador, baseado no trabalho escravo, e a chegada dos imigrantes europeus ao Brasil, inicia outra concepção sócio-econômica, abrindo espaço à pequena agricultura e a cultura de subsistência.

Nesse contexto, o processo migratório proporcionou ao país grandes mudanças sócioeconômicas, viabilizando novas perspectivas no processo produtivo agrícola, estabilidade da renda e ascensão do mercado interno.

Conforme afirma Furtado (2000, p.104), o aumento da corrente migratória permitiu maior disponibilidade da mão-de-obra qualificada. A partir de 1850, cerca de $130 \mathrm{mil}$ estrangeiros chegaram ao Brasil destinado às plantações de café, contribuindo para aumento da renda, a expansão do mercado interno e elevação dos níveis técnicos de produção.

Contudo, nota-se que no início da colonização brasileira a economia nacional era basicamente rural, mercado interno incipiente com a pauta exportadora pouco diversificada (açúcar, café, fumo, algodão, couro, borracha, etc), e economia dependente da demanda externa e vulnerável a crises.

Até 1970, ocorreram pouquíssimas mudanças na agricultura brasileira, que se mantinha como atividade extrativista. No entanto as inovações tecnológicas já davam sinais em algumas regiões do país, São Paulo e parte de Minas Gerais, onde se encontravam investimentos governamentais, tais como, infra-estrutura, pesquisas agrícolas, e cultivos de exportação.

Ao longo dos diversos ciclos vividos pela economia do país, na década de 90, graças às reformas comandadas pelo governo federal, houve um salto qualitativo na produção de bens agrícolas, diversificando a pauta exportadora do país, além de promover positivamente a economia brasileira.

A partir de 1990, inicia o acelerado crescimento do agronegócio brasileiro, com uso de tecnologias, diversificação dos produtos e serviços, o que conseqüentemente gera um salto na produtividade, colocando o país em posição de destaque no seu processo de desenvolvimento, bem como atuação no comércio exportador de commodities.

De acordo com França e Silva (2006), o agronegócio foi o setor que mais contribuiu para o saldo positivo da economia brasileira, no período de 1997 a 2005, sua 
contribuição foi de US $\$ 154,4$ bilhões, nesse período a balança comercial do país teve um saldo de US\$102,3 bilhões. Assim podemos observar que sem a contribuição do agronegócio a balança comercial teria um déficit de US\$52,1 bilhões (CORREIO DO ESTADO, 2006).

Atualmente, o Brasil estar em crescente expansão. Economistas apontam que, de acordo com o cenário atual, o país será a maior produtor agrícola do mundo nos próximos 10 anos. Dentre outros aspectos, condições climáticas favoráveis, terras agricultáveis em abundância fazem do Brasil um país com vocação natural para o agronegócio.

Segundo informações divulgadas na imprensa nacional, nos últimos anos, o Brasil se tornou um dos maiores produtores e fornecedores de alimentos do mundo. Em 2008 se tornou o terceiro maior exportador de produtos agrícolas, além disso, possui ampla capacidade de expansão.

Diante do exposto pode-se afirmar que a atividade agrícola brasileira sempre teve importância econômica, tanto externa como internamente. O setor vem se expandindo ao longo dos anos e promovendo boas perspectivas ao produtor rural, seja ele de pequeno, médio ou grande porte, pois sua atuação é ampla, e diante da competitividade imposta pelos mercados, cada qual busca medidas alternativas e novas técnicas de produção, visando a competitividades, qualidades e novos mercados.

\section{AGRICULTURA FAMILIAR E ECONOMIA SOLIDÁRIA NO BRASIL}

A agricultura familiar é um setor bastante antigo no mundo e nas relações comerciais que, ao longo dos anos, foi ganhando destaque devido a sua importância para a economia de uma nação através da geração de emprego, renda e alimento, além de favorece o emprego de práticas produtivas mais equilibradas, como a diversificação de cultivos, a preservação do patrimônio genético e a conservação do meio ambiente.

Em meio as constantes modificações produtivas e mercadológicas, principalmente na agricultura familiar, surge uma economia alternativa, fundamentada no cooperativismo, que valorizar o ser humano, o trabalho, o desenvolvimento sustentável. É de extrema importância a conceituação da Economia Solidária para que se possa melhor compreender o que se discute no presente trabalho. Para tanto, será traçado seus aspectos fundamentais, objetivos alcançados durante sua trajetória bem como algumas experiências no Brasil.

\section{AGRICULTURA FAMILIAR}

Antes de usar consensualmente a expressão Agricultura Familiar, até meados dos anos de 1990, falava-se em "pequena produção", "pequena agricultura", "agricultura de baixa renda" ou até "de subsistência", expressões que indicavam fragilidade e falta de perspectivas. Praticamente metade dos estabelecimentos familiares, os 2,8 milhões correspondentes aos segmentos mais pobres, produzem apenas 7,7\% do valor bruto da produção agropecuária. A sobrevivência dos que vivem nestas unidades marcadas por extrema pobreza se garante basicamente com a aposentadoria e, mais recentemente, com tranferência direta de renda, sob a forma de bolsarenda, seguro contra a seca, 
participação no Programa de Erradicação do Trabalho Infantil e outros. A característica central das regiões de muita pobreza é que seus mercados tendem a ser imperfeitos e incompletos. Reina agonia financeira com grandes dificuldades de acesso ao crédito e falta de assistência técnica (KUSTER; MARTÍ, 2004).

Para Sousa (2009, apud BRASIL 2005, p. 1), a agricultura familiar é conceituada como uma forma de produção em que predomina a interação da gestão com o trabalho, cujo processo produtivo é dirigido pelos agricultores familiares, enfatizando a diversificação e utilizando o trabalho familiar, eventualmente complementada pelo trabalho assalariado.

$\mathrm{Na}$ agricultura familiar, o negócio é administrado pela própria família, trabalhando com ou sem o auxílio de terceiros, onde o empreendimento funciona, ao mesmo tempo, como uma unidade de produção e de consumo.

A agricultura familiar merece especial atenção pelo seu significado para a saúde humana porque é responsável por boa parte da produção de alimentos básicos, tais como: feijão, mandioca, milho, leite, arroz, frutas e hortaliças.

No Brasil, a agricultura familiar é um tema relativamente novo que com o passar do tempo foi se rompendo os preconceitos, devido às modificações das políticas de fomento voltadas para o setor.

Na década de 90, o processo de abertura comercial do Brasil afeta a agricultura do país, além disso, o aumento da concorrência atrelada à dificuldade do acesso ao crédito leva os agricultores a cobrarem das autoridades suas reivindicações. Com isso, muda o rumo do desenvolvimento rural, na esfera governamental, culminando na criação, em 2004, do Programa de Valorização da Pequena Produção Rural (PROVAP), que posteriormente daria origem ao Programa Nacional de Fortalecimento da Agricultura Familiar (PRONAF), (SOUSA, 2009, p. 55).

De acordo com o relatório do projeto de Cooperação Técnica INCRA/FAO- Novo Retrato da Agricultura Familiar (2000, p.17), no Brasil há 4,9 milhões de estabelecimentos rurais, ocupando uma área de 35,6 milhões de hectares. Calcula-se que 4,1 milhões $(85,2 \%)$ são estabelecimentos familiares, ocupando $30,5 \%$ da área total e sendo responsáveis por $38 \%$ do Valor Bruto da produção da Agropecuária (VBPA) nacional (SOUSA, 2009, p. 45).

Ainda segundo esse relatório, a região Nordeste apresenta o maior número de agricultores familiares, correspondendo a 2,1 milhões de estabelecimentos, o que representa $51,2 \%$ dos estabelecimentos familiares do país, ocupando $43,5 \%$ de área total dos estabelecimentos rurais do Nordeste, responsáveis por cerca de $43,0 \%$ de todo o VPBA dessa região (SOUZA, 2009, p. 46).

A agricultura familiar é uma das importantes bases de produção no Nordeste brasileiro, com destaque para a produção de alimentos, ocupando parcela considerável da população. Os dados mostram que a presença de pequenas unidades de cultivo nos tabuleiros costeiros do Nordeste (Maranhão, Piauí, Rio Grande do Norte, Paraíba, Pernambuco, Sergipe e Bahia) é uma constante. No geral, as pequenas propriedades 
dedicam-se aos cultivos de mandioca, feijão, milho, fruticultura e à pecuária (TAVARES, 2009, apud SILVA et al., 1992).

Desse modo, pode-se considerar a agricultura familiar brasileira, como grande precursora do desenvolvimento do país, tanto pelo seu expressivo potencial econômico, como pela sua atuação sócio-cultural e ambiental na comunidade na qual estar inserida.

Apesar dos avanços alcançados, nas últimas décadas pelo setor, ainda há muito que melhorar. É notória a expressiva participação da agricultura familiar na economia do Brasil, no entanto, os elevados custos bancários, falta de assistência técnicaeducacional, dificuldade no acesso ao crédito, dificultam a sustentabilidade de algumas ações, dificultando a integração e alimentando as disparidades existentes nesse universo.

De acordo com Sousa (2009, apud CORRÊA; SILVA, 2007), o grupo economicamente integrado tem recebido benesses desta integração e conseguiu fazer parte do processo de modernização conservadora. Paralelamente, os agricultores menos integrados foram alijados do processo de modernização e tiveram baixo acesso ao sistema de crédito.

Além das novas ações políticas voltadas para o setor, o surgimento, nas duas últimas décadas, da produção ecológica no Brasil, que vem se desenvolvendo a passos largos, movida, num primeiro momento, pelo desejo de alguns técnicos e agricultores de encontrar saídas para as mazelas da agroquímica. Nesse cenário, o surgimento de demandas do mercado externo deu lugar às exigências de que os produtos ecológicos passassem a ser certificados. Pressionado pelas certificadoras, por algumas ONGs e organizações de agricultores, por potenciais processadores e exportadores de produtos orgânicos, o Ministério da Agricultura deu início a um debate que resultou na elaboração de um projeto de lei que regulamenta a produção orgânica no Brasil. Criaram-se a Câmara Setorial de Agricultura Orgânica e o Colegiado Nacional de Produtos Orgânicos, com a missão de credenciar, acompanhar e fiscalizar as certificadoras (KUSTER; MARTI, 2004).

As maiores dificuldades para o pequeno agricultor tratam-se das limitações de recursos, falta de acesso e articulação com o mercado. Restringido, na maioria dos casos ao mercado local, e mesmo dispondo de crédito e de assistência técnica, o agricultor rural torna-se dependente dos intermediários. No entanto, essa realidade está mudando, visto que a agricultura familiar brasileira, que vem mostrando sua importante atuação sócioeconômica no país, especialmente na região Nordeste, onde se encontra grandes números de agricultores mutuamente organizados, objetivando o desenvolvimento sustentável-ecológico, voltado para a Economia Social e Solidária, inserido no mercado internacional.

\section{ECONOMIA SOLIDARIA}

A economia solidária trata-se da valorização social do trabalho humano, que busca a satisfação das necessidades de todos como eixo da criatividade tecnológica e da atividade econômica, reconhecendo o lugar fundamental da mulher e do feminismo numa economia fundada na solidariedade, que busca uma relação de intercambio respeitosa com a natureza, e com os valores da cooperação e da solidariedade (SOUZA; CUNHA; DAKUZAKU, 2003). 
A organização social precedeu a organização econômica, esta estabelecida com a fixação do homem na terra através da produção e da distribuição de bens e serviços para suprir as necessidades do consumo coletivo. Com o passar dos anos, especialmente a partir da década de 90, devido a globalização, a evolução tecnológica, intensifica-se a proposta de que o mundo deve ser solidário, na esfera governamental, no mercado e nas relações humanas.

Nesse cenário surge a idéia de que o assistencialismo deve ser voltado para o outro, promovendo o bem estar social, objetivando garantir a competitividade diante da atual concorrência mercadológica. Nesse cenário a competitividade passa ser um das principais questões do mundo empresarial, especialmente para aquelas empresas inseridas na Economia Solidária, baseada na vantagem competitiva sustentável.

Para Porter (1985), a vantagem competitiva surge fundamentalmente do valor que uma empresa consegue criar para seus compradores e que ultrapassa o custo de fabricação pela empresa. Nesse contexto existem dois tipos de vantagens competitivas: liderança de custos e diferenciação.

Nos empreendimentos de Economia Solidária a vantagem competitiva pode se configurar, tanto no custo da produção, relativamente baixos, como na diferenciação do produto, pois, na maioria dos casos a Economia Solidária se desenvolve nos empreendimentos que realizam trabalhos artesanais tendo como base a autogestão e o desenvolvimento sustentável.

Segundo Irion (1997), a economia existe como instrumento para prover a população de bens e serviços de que necessita. Por tanto, nada mais justo que o foco de organização econômica se desloque para quem tem direito de usufruir dos benefícios por ela gerados- no caso as pessoas. Surgiu assim uma alternativa cuja base da organização econômica é a pessoa, proposta esboçada em meados do século XIX, com a prática do associativismo, do cooperativismo e do mutualismo, conjunto de organizações que reunidas formam a economia social e solidária cujo objetivo é desenvolver empreendimentos que envolvam pessoas, proporcionando melhores oportunidades de ocupação e realização como ser humano, como produtores e consumidores.

A lógica dessa economia alternativa se fundamenta na crítica operária e socialista ao capitalismo, período marcado pela extrema exploração da classe trabalhadora, que cumpria longas jornadas de trabalho em troca de salários baixíssimos e viviam em condições subumanas no local de trabalho, indústrias instaladas nos países que vivenciavam a revolução industrial.

Em meados da década de 70, devido a uma nova crise do capital, ou seja, uma crise no padrão de acumulação capitalista houve uma reestruturação produtiva, alterando novamente este quadro, com sérias conseqüências a classe trabalhadora: criou-se um quadro dramático, com reestruturação e fechamento de empresas, elevando os índices de desemprego a níveis nunca vistos.

Nesse momento o mercado de trabalho se tornou muito seletivo, passando a exigir trabalhadores altamente qualificado, capaz de operar simultaneamente máquinas modernas, e solucionar os mais diversos tipos de problemas provenientes do processo produtivo. Esta nova situação na realização do trabalho retirou do mercado formal uma 
grande massa de trabalhadores. Poucos puderam desfrutar dessa situação, as grandes maiorias foram buscar formas alternativas para sobreviver.

Neste cenário, a economia solidária surge como uma proposta alternativa a massa trabalhadora, viabilizando o desenvolvimento local e o fortalecimento com redes da cadeia produtiva espalhadas pelo mundo, com base em princípios éticos, solidário e sustentável.

Segundo Irion (1997), o autor classifica como princípios gerais da economia solidária, os principais pontos: a valorização social do trabalho humano; a satisfação plena das necessidades de todo o eixo da criatividade tecnológica e da atividade econômica; o reconhecimento do lugar fundamental da mulher e do feminismo numa economia fundada na solidariedade; a busca de intercambio respeitosa com a natureza; os valores da cooperação e da solidariedade.

A Economia Solidária (ES) se constitui no fundamento de uma globalização humanizadora, de um desenvolvimento sustentável, socialmente justo e voltado para a satisfação racional das necessidades de cada um e de todos os cidadãos da Terra seguindo um caminho internacional de desenvolvimento sustentável na qualidade de vida (FRANÇA FILHO; LAVILLE, 2006).

A economia solidária vem se desenvolvendo no mundo como uma poderosa ferramenta de combate á exclusão social, e a integração das redes de produção e consumo, através de alternativas de trabalho e renda, gerando benefícios e promovendo o bem estar comum, na sociedade na qual os indivíduos integrantes dessa cadeia, estão inseridos.

Para França Filho e Laville (2006), a Economia solidária é um poderoso instrumento de combate à exclusão social, pois apresenta alternativa viável para a geração de trabalho e renda e para a satisfação direta das necessidades de todos, provando que é possível organizar a produção e a reprodução da sociedade de modo a eliminar as desigualdades materiais e difundir os valores da solidariedade humana.

Diante do exposto pode-se afirmar que a economia solidária (ES) é um conjunto de atividades econômicas que visa organizar e realizar solidariamente um trabalho de forma coletiva, autogestora e centrada no ser humano, que nos os últimos anos tem ocupado espaços crescentes na atividade econômica, nas diversas esferas institucionais em diversos países do mundo.

Visando a essa nova dinâmica, bem como as transformações que ocorrem no cenário econômico atual, nota-se que os trabalhadores menos favorecidos, associados em cooperativas, buscam fôlego para sobreviver em meio à competitividade, com isso surgem as "novas formas de organização" que demanda uma nova engenharia de ação coletiva, novas formas de ações políticas e de gestão, é nesse contexto que a economia solidária vem fazendo a diferença na atuação das cooperativas que estão inseridas no mercado internacional ou que buscam consolidação em novos mercados.

Nesse cenário destacam-se os pequenos produtores rurais, que através de cooperativas e assistidos pelos programas de fomento ao setor buscam se manter no mercado, cada vez mais concorrido, e consumidores cada dia mais exigentes. 


\section{COOPERATIVISMO E ECONOMIA SOLIDÁRIA NO BRASIL}

Nas ultimas décadas o crescimento das atividades econômicas ultrapassaram as fronteiras de inúmeros países desencadeando o processo da globalização, nesse contexto surge diversos benefícios para a economia mundial, em termos de produtividade e de eficiência na utilização de recursos produtivos. No entanto, o mesmo não ocorre em relação ao desenvolvimento social nas nações, influenciadas por tal processo, com aspectos peculiares como o Brasil. Esse cenário gera diversos problemas para a sociedade menos favorecida, dentre eles, destacam-se, falta de garantias às condições mínimas de sobrevivência digna e subemprego, fazendo com que uma grande massa, atingida por esses problemas sócio-econômicos busquem alternativas através do Cooperativismo, que é uma forma de economia social e solidária.

Devido a esse novo cenário da economia mundial se aprofundam a idéia de cooperativa como uma organização que pode facilitar o combate às desigualdades sociais, e que a eliminação dos intermediários entre o produtor e o consumidor, poderia diminuir o preço, proporcionando melhores condições de competitividade dos produtos e serviços.

De acordo com Santos (2008), o cooperativismo iniciou-se em meados do século XIX (Pioneiros de Rochdale) como reação ao desemprego decorrente da Revolução Industrial e à opressão exercida sobre os trabalhadores pelos proprietários dos meios de produção. Ainda segundo a autora, no início, apresentou fases de significativo crescimento, mas atravessou períodos de reconhecido declínio, como por ocasião do pleno emprego proporcionado pela implantação do Plano Marshall na Europa e Japão. No Brasil, vem surgindo como alternativa ao desemprego massivo ocasionado pela globalização da economia, aplicando-se a vários casos, com grande qualidade e produtividade.

Internacionalmente as cooperativas organizam-se sob assistência da Aliança Cooperativa Internacional (ACI), criada em 1895. No continente americano essa articulação é feita pela Organização das Cooperativas da América (OCA) - fundada em 1963, atualmente com sede em Bogotá, Colômbia, integrando representações de vinte países, inclusive o Brasil (SANTOS, 2008). Essas normas servem de orientação para o relacionamento entre cooperativa e cooperados e desses entre si, conhecidos como os Princípios do Cooperativismo.

$\mathrm{Na}$ literatura especializada, o termo, Cooperativa possui diversas definições, variando conforme linha doutrinária e época em que foram desenvolvidas. O Cooperativismo ocorre nas mais diversas sociedades, seja primitiva ou moderna, em todas as culturas, e independente do termo utilizado para sua descrição a essência dessa doutrina não muda, já que as sociedades de cooperativas surgem para que as pessoas, com objetivos em comum, juntas possam alcançar seus anseios.

Segundo Kreutz (2004), cooperativismo é um movimento internacional, que busca constituir uma sociedade justa, livre e fraterna, em bases democráticas, através de empreendimentos que atendam às necessidades reais dos cooperantes, e remunerem adequadamente a cada um deles cujos valores são: ajuda mútua e responsabilidade, democracia, igualdade, equidade e solidariedade.

A autora destaca ainda os sete princípios do cooperativismo: Adesão voluntária e livre; Gestão democrática pelos membros; Participação econômica dos membros; Autonomia 
e independência; Educação, formação e informação; Intercooperação e Preocupação com a comunidade.

As cooperativas visam o trabalho para com vistas ao desenvolvimento sustentável das suas comunidades, através de políticas aprovadas pelos seus membros. É uma das formas avançadas de organização da sociedade civil que proporciona $o$ desenvolvimento sócio-econômico aos seus integrantes e à comunidade; resgata a cidadania através da participação, do exercício da democracia, da liberdade e autonomia, no processo de organização da economia e do trabalho (KREUTZ, 2004).

Para Dabello e Frans (2006), a cooperação vem como forma de incluir o pequeno produtor de forma sustentável no mundo globalizado e competitivo, dividindo as responsabilidades e superando as inseguranças ao mesmo tempo em que potencializa a força do trabalho, as virtudes e habilidades dos envolvidos. O cooperativismo é, portanto, um tipo de organização coletiva que se configura como Economia Solidária.

Basicamente o que se procura ao organizar uma Cooperativa é melhorar a situação econômica de determinado grupo de indivíduos, solucionando problemas ou satisfazendo necessidades comuns, que excedam a capacidade de cada indivíduo satisfazer isoladamente.

No Brasil, o Cooperativismos surge, somente no final do século XIX, na zona rural do país, desde então, tem evoluído ao ponto de ser constituído em política nacional. A representação de todo o sistema cooperativista nacional cabe à Organização das Cooperativas Brasileiras (OCB), que se institucionalizou legalmente através da lei federal 5.764/71 de 16/12/1971 (SANTOS, 2008).

A organização social através do cooperativismo respeita a individualidade de cada família, ou grupo, na sua forma de trabalhar, na sua maneira de ser, oferecendo condições plenas de se inserir na sociedade com maior poder de negociação e organização (DABELLO; FRANS, 2006).

De acordo com Souza (2008), uma das mais características formas de expressão do autêntico cooperativismo é a Economia Solidária. Pode-se defini-la como a ação capaz de gerar novas oportunidades e inserção social por meio do trabalho, desde que revestida de alguns valores que a legitimem: democratização da gestão do trabalho ajuda mútua, responsabilidade, equidade e solidariedade, domínio do "know-how" produtivo, distribuição equitativa de renda obtida e fortalecimento do desenvolvimento local de forma auto-sustentável.

A auto-gestão dos empreendimentos cooperativistas, é permeada pelos valores éticos da honestidade, transparência e responsabilidade social, é nesse contexto que a Economia Solidária agrega o conjunto das empresas que claramente se regem pelos princípios do cooperativismo, ou seja, a autogestão, à exemplo, a Cooperativa de Produção que essencialmente pode ser considerada a unidade básica da Economia Solidária.

Segundo Bocayuva e Varanda (2009), no Brasil, o novo cooperativismo, que rompe com a tradição do cooperativismo rural associado a uma gestão capitalista, abriga-se sobre o conceito de economia popular e solidária. Segundo o Sistema Nacional de Informação em Economia Solidária (SIES, 2006), foram identificados 21.857 
empreendimentos solidários no Brasil, perfazendo um total de 1 milhão e 751 mil trabalhadores associados.

A Economia Solidária (ES) começa a se desenvolver no Brasil devido ao renascimento dos movimentos sociais, com a propagação da crise social desencadeada pela abertura do mercado interno às importações, ação que cominou no fechamento de empresas, redução dos postos de trabalho e da produção e consequentemente aumento do desemprego.

Segundo Gonçalves (2003, apud SINGER; SOUZA 2000), a Economia Solidária começou a ressurgir no Brasil na década de 1980, mas tomou impulso crescente a partir da segunda metade dos anos 1990 como resposta dos movimentos sociais à crise do desemprego, agravada pela abertura do mercado brasileiro ao comércio internacional. $\mathrm{Na}$ agricultura, surge através do Movimento dos Sem Terra (MST), que organiza diferentes tipos de cooperativas nos assentamentos. No setor industrial, assessores sindicais orientam trabalhadores a se organizarem na forma de cooperativas de produção para assim manter postos de trabalho ameaçados pela crise econômica. Como decorrência do movimento da ação da cidadania, surgiu em meados dos anos 1990 as incubadoras tecnológicas de cooperativas populares, ligadas às universidades e que dão apoio à população em geral para formação ideológica e a constituição e gestão de cooperativas de trabalho e de produção. Várias outras iniciativas vão se reunindo a estas, fortalecendo a constituição de uma organização econômica paralela fundada em princípios éticos e reguladores de mercado: as trocas solidárias.

No Brasil, as primeiras iniciativas da Economia Solidária encontram-se sob a denominação genérica de bancos populares, a experiência pioneira é o banco de palmas no Ceará, organização popular e solidária que muito extrapola as ações de microcrédito. Trata-se da iniciativa da Associação dos Moradores do Conjunto de Palmeiras (Asmoconp), um bairro/favela, com clara inserção política de luta dos moradores em torno da construção do seu próprio bairro. São inúmeros os projetos fomentados: de cooperativas de produção de artesanato, confecções e limpeza, passando por iniciativas de clubes de troca e de consumo solidário (FRANÇA FILHO e LAVILLE, 2006).

Outro exemplo diz respeito à Associação dos Pequenos Agricultores do Município de Valente (Apaeb), no interior da Bahia. Esta associação desenvolve diversas atividades de industrialização e comercialização de produtos agrícolas, além de conselhos técnicos e capacitação de produtores, manejo de tecnologia socialmente apropriada, concessão de crédito, uma escola-família agrícola, etc (FRANÇA FILHO; LAVILLE, 2006).

De acordo com Bocayuva e Varanda (2009), as universidades públicas brasileiras, nos últimos 13 anos, têm assumido um papel importante na incubação de empreendimentos solidários. Destacam-se por atuar na junção de ações junto a pesquisa e extensão universitária cujo enfoque centra-se na Economia Solidária e na economia popular. Segundo os autores, atualmente existem no interior das Instituições de Ensino Superior pelo menos 100 Incubadoras Tecnológicas que atuam com empreendimentos de ES.

Ainda segundo os autores, as Incubadoras Tecnológicas de Cooperativas Populares (ITCP's), no âmbito acadêmico, se estruturam na relação direta com o movimento social da ES que vem ganhando novas dimensões por meio de fóruns de Economia Solidária municipal, estadual e nacional. Garantindo a formação contínua tanto dos 
professores, pesquisadores, técnicos e bolsistas como dos trabalhadores envolvidos no processo (BOCAYUVA; VARANDA, 2009).

Isto é apenas uma pequena amostra das transformações que essa economia alternativa vem promovendo na sociedade brasileira, desde que a massa trabalhadora resolveu promover movimentos pelos direitos sociais, melhores condições de trabalho e renda, almejando o desenvolvimento local em prol da produção e do consumo coletivo através da Economia Solidária.

Devido a esse "surto" da ES, nas últimas décadas, foram criadas diversos órgãos, visando a promoção dessa economia alternativa no país, além de promover o acesso aos fomentos e a educação, aqueles pequenos produtores que estão localizados em regiões de difícil acesso e pouca informação, tendo como um dos objetivos principais, intensificar as redes de comércio. Dentre essas entidades destaca-se a Cáritas, ligada a Conferência Nacional dos Bispos do Brasil (CNBB), que desde 1980 já financiava milhares de pequenos projetos denominados PACs, Projetos Alternativos Comunitários (FRANÇA FILHO; LAVILLE, 2006).

Dentro desse contexto o Movimento dos Sem Terra (MST) pode ser considerado um agente relevante no apoio e fomento a Economia Solidária (ES), assim como a Central única dos trabalhadores (CUT), a Agência de Economia Solidária (ADS), dentre outros. Todos eles agindo em prol do desenvolvimento local sustentável e solidário. Além dessas entidades, destacam-se também os meios de comunicação com extrema importância para a divulgação da ES, a exemplo a internt que vem ajudando a difundir essa nova concepção econômica no Brasil e no mundo. A Economia Solidária é tema de debate em todas as esferas em potencial, seja no meio acadêmico, político, econômico e social, visando o proliferação dessa nova visão através de políticas com vista ao bem comum.

Uma experiência brasileira de política econômica solidária trata-se da criação da Secretaria Nacional de Economia Solidária (SENAES), criada em 2003, por iniciativa do Governo Lula, o candidato que e colocou a ES como destaque no seu programa de governo. A SENAES conta com coordenadorias de microcrédito e comercialização, de desenvolvimento local solidário, formação de economia solidária, estudos e divulgação (FRANÇA FILHO; LAVILLE, 2006).

O mapeamento da evolução da economia solidária no Brasil tem mostrado um grande avanço nos Empreendimentos Econômicos Solidários (EES), principalmente na região Nordeste, já que as maiores partes desses empreendimentos tratam-se de atividades desenvolvidas entre os grupos familiares produzindo em pequena escala, geralmente voltados ao setor agrícola.

Segundo a Cartilha da Campanha da Fraternidade (2010), o Sistema de Informações em Economia Solidária (SIES) identificou, entre 2005 e 2007, 21.859 Empreendimentos Econômicos Solidários (EES). Nesses empreendimentos estão associados/as cerca de um milhão e setecentos mil homens e mulheres. A pesquisa foi realizada em 2.934 municípios (52\% dos municípios brasileiros) pela Secretaria Nacional de Economia Solidária, em parceria com o Fórum Brasileiro de Economia Solidária. Segundo os dados apurados na pesquisa os principais motivos para a criação dos EES são: alternativa ao desemprego (46\%) e complemento da renda dos sócios (44\%). 
Para França Filho e Laville (2006, p. 77), a economia solidária ressurge hoje como resgate da luta histórica dos (as) trabalhadores (as), como defesa contra a exploração do trabalho humano e como alternativa ao modo capitalista de organizar as ralações sociais dos seres humanos entre si e destes com a natureza.

Diante do exposto pode-se afirmar que a economia solidária tem uma dinâmica própria, que seu desenvolvimento de pende da criação de novas instituições solidárias, para tanto as políticas de fomento são importantes para ajudar os pobres e a auto-organização desse sistema de ação solidária na luta pelo comércio justo.

\section{ATIVIDADE DA CAJUCULTURA}

A fixação da população em diversos pontos das regiões brasileiras ocorreu devido aos ciclos de atividades econômicas que o país vivenciou durante a sua ocupação territorial. Com isso foi estabelecido os focos de povoamento que desenvolveram as atividades econômicas e sociais de acordo com as condições oferecidas pela região ocupada, naquela época.

No Rio Grande do Norte, no início da colonização a economia era basicamente de subsistência, destacando a pesca, a agricultura e a pecuária.

Atualmente a economia está em pleno desenvolvimento, com destaque para a agricultura, pecuária, pesca, extração vegetal e mineração.

Segundo dados do IBGE, o Produto Interno Bruto (PIB) no Rio Grande do Norte cresceu 4,8\% de 2002 a 2006, atingindo R $\$ 20,5$ bilhões nesse período. O agronegócio, com destaque para o segmento da fruticultura, foi o setor que mais contribuiu para impulsionar a economia do estado (NOMINUTO, 2008).

Inserida nesse cenário, a castanha de caju, objeto de estudo deste trabalho, tem se destacado na pauta exportadora do estado nos últimos anos devido ao crescente investimento das cooperativas e indústria de beneficiamento do produto, instaladas no estado, estar desenvolvendo a economia local e regional com crescentes investimentos no setor da cajucultura.

\section{CAJUCULTURA NO BRASIL E NO MUNDO}

O cajueiro cuja classificação científica é Anacardium occidentale, árvore típica originária da região litorânea brasileira, com concentração produtiva na região Nordeste. De cultura perene, tanto o pedúnculo quanto a amêndoa de castanha são produtos de alto valor nutritivo, além de apresentarem diversas possibilidades de aproveitamento dos seus derivados na indústria alimentícia.

No cenário internacional a cajucultura está espalhada em diversos países do mundo, com destaque para o Vietnã, Índia, Nigéria e Brasil.

Segundo Oliveira e Rocha (2009), a oferta mundial de castanha de caju in natura tem crescido aceleradamente nos últimos anos. A produção elevou-se em 59\% entre 2000 e 2006, alcançando 3,1 milhões de toneladas, enquanto a área colhida sofreu incrementos de apenas 18,4\% no mesmo período. Em conseqüência, a produtividade média saltou de 
$681,7 \mathrm{~kg} / \mathrm{ha}$ em 2000 para 916,2 kg/ha em 2006. Estas elevações dos índices de produtividade estão associadas ao desenvolvimento de melhorias genéticas e de técnicas de manejo e ao crescimento do cultivo de cajueiros anão-precoce.

No Brasil, os principais estados produtores são: Piauí, Ceará e Rio Grande do Norte, sendo maior parte da produção exportada para os mercados europeu, americano e asiático. No mercado interno o consumo ainda é insipiente, ensejando potencial a ser explorado. A ampliação desse mercado depende fundamentalmente do padrão de qualidade do produto associado a campanhas de marketing que informem a população das vantagens nutritivas, terapêuticas que a amêndoa de castanha de caju possui, bem como o valor nutricional do pedúnculo, pouco aproveitado na indústria alimentícia brasileira.

Segundo dados da Companhia Nacional de Abastecimento do Rio Grande do Norte (CONAB-RN), nos últimos anos os estados nordestinos vêm exportando, em média, US\$ 115 milhões de amêndoa/ano. Somente nos quatro primeiros meses de 2003 o Nordeste exportou o equivalente a US\$ 39.4 milhões, contra US\$ 31,0 milhões do mesmo período do ano anterior, representando um acréscimo de $27 \%$ no período, caracterizando-se como importante fonte geradora de divisas para a região (COSTA, 2009).

Ainda segundo dados da CONAB-RN, os Estados do Ceará, Piauí e Rio Grande do Norte respondem por mais de $80 \%$ da produção nacional de castanha de caju in natura, sendo que mais de $80 \%$ dessa produção é exportada para os mercados europeu, americano e asiático, sob forma de amêndoas (COSTA, 2009).

A importância do cajueiro como atividade econômica para o Rio Grande do Norte remonta ao final dos anos 1960 e início da década de 1970, quando a Maísa - Mossoró Agroindustrial S/A, implantou uma área de 12 mil hectares destinada a produzir matéria-prima para a indústria (castanha e suco). Posteriormente o Governo do Estado criou um grande projeto de colonização na Serra do Mel, visando a instalação de vilas rurais e o desenvolvimento da cultura do cajueiro em 18 mil hectares, como base de sustentação econômico- financeira do empreendimento (REVISTA SEBRAE AGRONEGÓCIOS, 2007).

No Rio Grande do Norte a produção e o beneficiamento da Amêndoa de Castanha de Caju (ACC) está em expansão, com condições favoráveis às exportações o produto vem atuando com participações expressiva na pauta exportadora do estado nos últimos 4 anos.

As estatísticas da Secretaria de Comércio Exterior (SECEX) revelam que, no ano de 2007, o RN exportou 256,8 mil toneladas de frutas (15 mil toneladas a mais que 2006), o que rendeu um faturamento de US\$173,3 mi. Em 2006, o total exportado foi de US\$ 144,3 milhões.

Segundo Costa (2009), a safra de castanha de caju do Rio Grande do Norte de 2008/2009 totalizou a produção em 42.877 toneladas - dados do IBGE. É nesse cenário que a castanha de caju vem se configurando como fonte de descentralização de renda e geração de emprego nas comunidades envolvidas com a cajucultura no Brasil e no mundo. 


\section{PRINCIPAIS MUNICÍPIOS PRODUTORES DE ACC NO RN}

A produção e customização da Amêndoa de castanha de caju nos municípios do Rio Grande do Norte vêm expandindo ao longo dos anos devido às políticas públicas de incentivos aos pequenos e médios produtores rurais, que juntos estão buscando fôlego, organizados em cooperativas, visando maior qualidade e competitividade da amêndoa destinada ao mercado externo.

A agroindústria de processamento e beneficiamento de castanha de caju utiliza principalmente à castanha, sendo o pedúnculo aproveitado pelas indústrias de sucos, doces, geléias, entre outros. A castanha representa mais de $90 \%$ da renda gerada pelo beneficiamento desta fruta no Brasil.

Por tanto, levando em consideração o fato de que a produção do caju é sazonal, entendese que há muito à ser feito para aproveitar $100 \%$ da fruta e garantir emprego e renda, o ano todo, para as comunidades que exploram a cajucultura.

Nos últimos anos, vêm sendo implantado o Projeto Mini-fábricas de Castanha de Caju em alguns municípios do estado, além de uma central de comercialização, abrangendo os municípios de Serra do Mel, Apodi, Portalegre, Caraúbas, Macaíba, Martins, Mossoró e Touros. No estado, os investimentos superam R\$ 1,2 milhão (REVISTA SEBRAE AGRONEGÓCIOS, 2007).

Tabela 1 Principais municipios produtores de castanha de caju do estado do rio grande do norte

\begin{tabular}{|c|c|c|}
\hline MUNICÍPIO & ÁREA (ha) & PARTICIPAÇÃO (\%) \\
\hline SERRA DO MEL & 21.000 & 18,6 \\
\hline MACAÍBA & 14.000 & 12,4 \\
\hline MOSSORÓ & 8.000 & 7,1 \\
\hline PUREZA & 6.500 & 5,8 \\
\hline LAGOA NOVA & 5.326 & 4,7 \\
\hline APODI & 5.000 & 4,4 \\
\hline TOUROS & 4.550 & 4,0 \\
\hline AREIA BRANCA & 4.100 & 3,6 \\
\hline SÃO BENTO DO NORTE & 3.000 & 2,7 \\
\hline CERRO CORÁ & 3.000 & 2,7 \\
\hline JOÃO CÂMARA & 2.800 & 2,5 \\
\hline CARAÚBAS & 2.600 & 2,3 \\
\hline PORTALEGRE & 2.150 & 1,9 \\
\hline GALINHOS & 2.000 & 1,8 \\
\hline CAIÇARA DO NORTE & 2.000 & 1,8 \\
\hline OUTROS & 26.710 & 23,7 \\
\hline TOTAL & 112.736 & 100 \\
\hline
\end{tabular}

Elaboração: CONAB-RN, 2003. 
No caso da Unidade de Beneficiamento de Castanha da Serra do Mel, 172 famílias são beneficiadas diretamente, processando e exportando a produção para países da união européia. Além da produção da Serra do Mel, que tem 2,5 milhões de pés de cajueiros, a unidade também exporta a produção de pequenos produtores de Apodi, Caraúbas e Portalegre (JORNAL DEFATO, 2009).

Atualmente, as minifábricas têm convênio com a Companhia Nacional de Abastecimento (CONAB) - que fornece crédito para cada unidade adquirir castanhas in natura dos associados -, além de mercados locais e prefeituras, que distribuem o produto em merendas escolares. Cada minifábrica oferece, em média, 30 postos de trabalho diretos (JORNAL DEFATO, 2009).

O modelo de minifábricas de processamento de castanha de caju, envolve novos avanços, como a implementação de equipamentos que permitem obter um produto com melhor qualidade e a inserção de pequenos produtores ligados à agricultura familiar. $\mathrm{O}$ objetivo é a obtenção do maior número de castanhas inteiras e alvas, assegurando as exigências do mercado internacional, altamente exigente e competitivo.

Os investimentos que estão sendo implementados, no projeto de minifábricas, visa a minimização da perda da matéria-prima nos períodos de safra cuja produção engloba castanha crua, torrada, sendo que a fruta recebe um beneficiamento mínimo durante a época de safra para ser armazenada e processada ao longo do ano, garantido a oferta do produto nos períodos de entressafra.

De acordo com a Unidade de Agronegócios do Serviço de Apoio às Micro e Pequenas Empresas (SEBRAE) Nacional, o processo de beneficiamento da castanha de caju tem as seguintes etapas:

A secagem das castanhas é feita em quadras de cimento ou em terreiros com o objetivo de reduzir a umidade para em torno de $8 \%$. Depois de limpas, são classificadas e armazenadas em local arejado e seco. Dessa forma, é possível estocar por até um ano enquanto se aguarda o beneficiamento.

A industrialização da castanha de caju começa com o cozimento por aproximadamente 20 minutos em autoclaves. Depois que saem das autoclaves, as castanhas seguem para o corte. O trabalho é feito preferencialmente em duplas. Uma pessoa opera a máquina de corte e a outra ajuda a separar a amêndoa da castanha.

A amêndoa, já sem a casca, passa por outras etapas de beneficiamento. Para reduzir a umidade, é preciso colocar as amêndoas em estufas por seis a oito horas. Depois de esfriar por duas a três horas, seguem para o umidificador. Isso facilita a próxima etapa de beneficiamento: a despeliculagem.

Neste processo, a retirada de películas é feita primeiramente com a utilização de equipamento. Em seguida, vem o acabamento manual, que garante melhor qualidade final e redução do percentual de quebra das castanhas. Nesta etapa, as amêndoas são separadas em grupos por tamanho, integridade e cor, para atender as demandas do mercado comprador. Em seguida, são embaladas. 
Os conceitos de classificação e especificação de qualidade são determinados pelo Ministério da Agricultura e estão de acordo com as normas internacionais. Atualmente, o produto in natura é destinado ao mercado externo.

Para o mercado interno, as amêndoas recebem outro tratamento. Depois de selecionadas, elas são fritas em óleo de qualidade por aproximadamente três minutos. Em seguida, vão para a centrifugação a fim de que seja retirado o excesso de óleo. Ainda quentes, são salgadas e embaladas.

Atualmente, o controle de qualidade vai além das exigências burocráticas dos órgãos de regulamentação e inspeção, envolve todos os níveis da empresa e do processo, atuando como uma estratégia fundamental e indispensável para garantir a competitividade. É nesse contexto que o trabalho das cooperativas que beneficiam a amêndoa de castanha de caju, que além de oferecer produto competitivo com qualidade, promove o comércio solidário nos empreendimentos que trabalham com o cultivo, processamento $\mathrm{e}$ comercialização da amêndoa.

\section{ESTUDO DE CASO NA COOPERCAJU (SERRA DO MEL-RN)}

O município de Serra do Mel, no Rio Grande do Norte, localizado a aproximadamente 285 quilômetros de Natal tem sua origem em um projeto de colonização agrícola da década de 60, desde então tem sido pioneira no beneficiamento artesanal de castanha de caju.

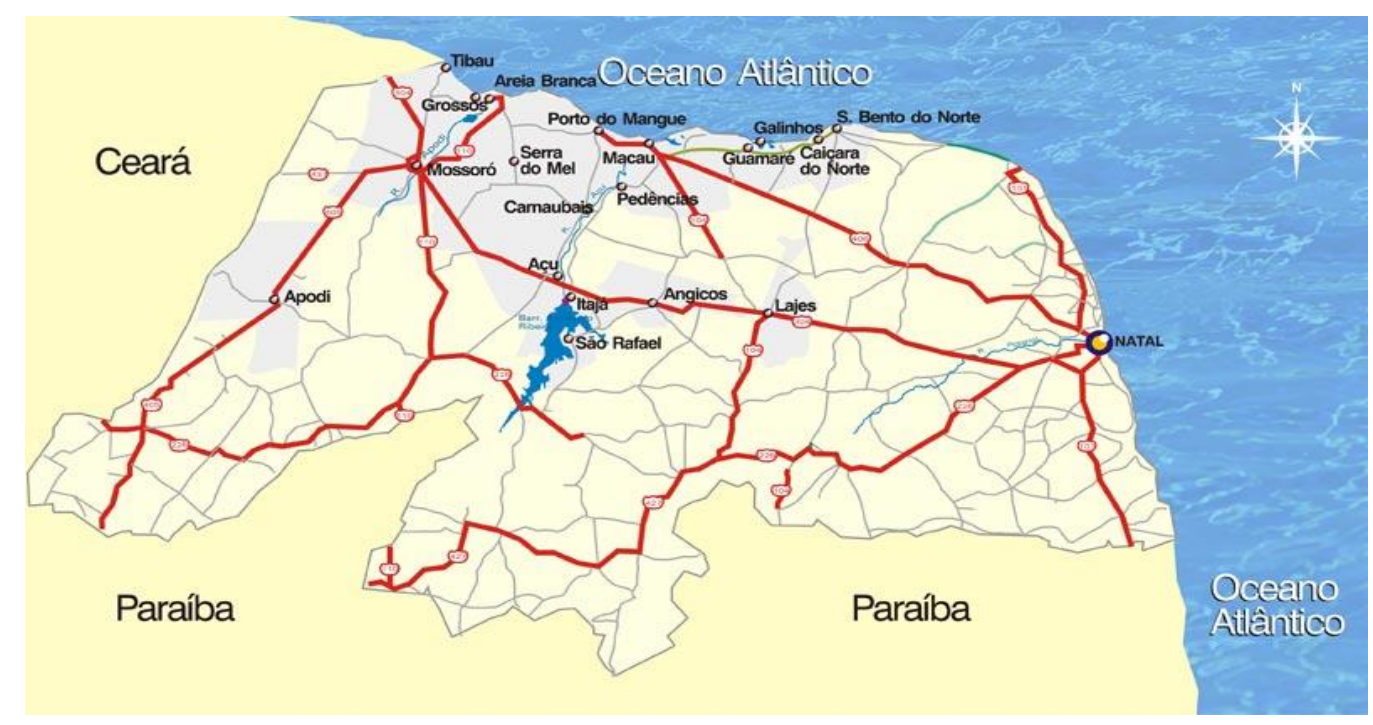

Mapa 1

Fonte: brasil-natal.com.br

Foi esse contexto que viabilizou o surgimento da organização de produtores e produtoras: A Cooperativa de Beneficiamento Artesanais de Castanha de Caju do Rio Grande do Norte (COOPERCAJU), cujo ramo de atuação é Castanha de Caju Orgânica e Convencional, fundada em 1991, mas o trabalho da comunidade com a cajucultura já vinha sendo desenvolvido desde o período de colonização da região. 
Conforme dados coletados na entrevista, a Cooperativa foi fundada em 25 de julho de 1991, mas o seu trabalho já vinha sendo desenvolvido quando se iniciou o processo de colonização do município de Serra do Mel. Projeto de colonização do governo federal, que surgiu devido ao alto índice de agrônomos, salineiros desempregados na região.

Serra do Mel foi distribuída em 23 vilas, cada uma com nome de um Estado brasileiro, cada lote varia o número de casas, que pode haver 22, 70, 80 casas, onde cada família recebeu 50 hectares de terra, sendo 15 hectares para o cultivo do cajueiro, 10 hectares para o cultivo da faixa branca, cultura de subsistência (milho, feijão...), e 25 hectares de mata, para área de preservação. Os lotes foram entregues já com as casas construídas a população, por isso é denominado colonização.

O processo de colonização proporcionou uma área muito extensa para o cultivo do cajueiro, onde os atravessadores e as grandes empresas começaram a adquirir a castanha e conseqüentemente obter altos ganhos em detrimento do baixo rendimento dos produtores, com isso os agricultores se juntaram para montar a cooperativa.

A entrevistada afirma que "os atravessadores compravam do jeito que queria, como queria, chegando ao ponto de uma das grandes empresas, chamarem os produtores de apanhadores de castanha: em Serra do Mel temos os nossos a apanhadores de castanha". Essa frase tocou os agricultores, que a partir dessa necessidade resolveram criar a cooperativa para trabalhar com o beneficiamento artesanal da castanha de caju, até então só comercializavam a castanha, onde o trabalho seria desenvolvido pelas famílias cooperadas.

Os pequenos agricultores, que produziam individualmente, sentiram a necessidade de se organizarem para expandir a comercialização da castanha, visto que o comércio local era insuficiente para absorver a significativa oferta.

Nesse cenário, iniciou uma nova fase para os agricultores do município, que ainda não tinham contato com o beneficiamento artesanal, mas começaram a desenvolver o processo de beneficiamento da amêndoa com ajuda técnica da Associação de Apoio às Comunidades do Campo (AACC), se aprimorando ano a ano.

Após essa fase inicial, surge a necessidade de conscientização da população local em relação ao consumo da amêndoa, até então, pouco consumida pelo mercado interno e com preços relativamente elevados.

Como todo projeto inovador, o começo não foi fácil, após superar as dificuldades de cultivo, manejo e beneficiamento, e também cultural, surgem os entraves comerciais. As exigências técnicas, mercadológicas e legislativas não são poucas, além disso, logo no começo da atuação da cooperativa o acesso ao mercado externo era muito restrito, no entanto, alguns desses desafios foram sendo superados.

Para sua primeira exportação a cooperativa teve uma ajuda da Igreja, bastante atuante no período de colonização da região, conforme afirma a entrevistada: "Na época, no início da colonização a igreja era muito presente, havia um padre italiano que levava algumas amêndoas pra parentes na Europa, a partir de então surge à primeira exportação da COOPERCAJU, em 1993, com 3.500 quilos". 
O processo de internacionalização também não foi fácil, principalmente por se tratar de alimento proveniente da agricultura familiar, e também pela carência de políticas públicas de incentivo ao setor, na época. Até as discussões com os órgãos de certificação, a exemplo, o Instituto Biodinâmico (IBD), foram complicadas, as exigências do IBD não eram possíveis de ser implantada numa unidade inserida na agricultura familiar, a maioria das exigências eram voltada para as grandes indústrias. Com o passar dos anos essa realidade foi mudando e, hoje vem sendo implantadas as e melhorias, ano a ano, safra a safra visando o melhor para o desenvolvimento do trabalho em todas as unidades de produção familiar, principalmente as de produção orgânica.

A IBD Certificações é uma empresa brasileira que desenvolve atividades de inspeção e certificação agropecuária, de processamento e de produtos extrativistas, orgânicos, biodinâmicos e de mercado justo (Fair Trade). Atua há mais de vinte e cinco no campo da pesquisa e desenvolvimento da agricultura orgânica e biodinâmica. O IBD iniciou seus trabalhos de certificação em 1990 e, desde então, opera em todo o território brasileiro e em alguns países da América do Sul, América Central, Europa e Ásia, auxiliando no desenvolvimento de um padrão de agricultura sustentável baseado em novas relações econômicas, sociais e ecológicas.

Na COOPERCAJU, a primeira certificação IBD foi em 1994, conforme afirma a entrevistada: "trocemos o IBD pro Nordeste, mas devido a uma grande seca o selo foi suspenso pela falta de produção, e em 2003, com a regularização do inverno, o selo foi retomado, desde então tem sido permanente".

Atualmente o Estado é muito presente na cooperativa, que sempre participa das discussões governamentais sobre a economia solidária, comércio justo, que melhorou com o governo Lula, e tem evoluído bastante nos últimos anos. A COOPERCAJU é referência nacional e Internacional nas ações governamentais voltadas para a Economia Solidária, feiras, eventos internacional, tudo patrocinado pelos programas sociais. Ao longo dos anos, vem sendo implantado melhorias viabilizando o trabalho desenvolvido pela unidade. O governo investe, na agricultura familiar, antes essa abertura ao mercado internacional não ocorria. Hoje, em Brasília, têm pessoas de fácil acesso que ajudam nas informações necessárias para inserção do produto da agricultura familiar no mercado internacional.

Inicialmente a cooperativa tinha uma empresa que comercializava o produto, pagava-se 4\% das vendas a uma trade para comercializar a amêndoa no mercado internacional, mas ao longo dos anos, os próprios clientes passaram a incentivar os sócios a se responsabilizarem, também, pela comercialização da amêndoa.

A partir de 2002, começou as preparações para a cooperativa comercializar seu produto no mercado externo sozinha. Esse trabalho iniciou pela atual gestora, que buscou ajuda junto à Receita Federal, preparou as documentações necessárias, e deu início ao processo. Atualmente, toda a documentação exigida para a exportação da amêndoa é feita na própria sede da cooperativa.

A castanha é escoada via modal marítimo e aéreo, sendo o porto de Fortaleza o mais utilizado por oferecer maior número de navios, as melhores condições de armazenamento e escoamento do produto. $\mathrm{O}$ porto de Natal é pouco utilizado devido à baixa frequiência de navios de carga por semana. Como eles frequentemente despacham 
Carga Consolidada, quantidade menor, priorizam a utilizar o porto de Fortaleza devido à maior rotatividade de navio. Em Natal, é mais utilizado o Aeroporto Internacional Augusto Severo.

Existe um despachante em fortaleza, já que são poucas pessoas habilitadas para desenvolver o trabalho burocrático e comercial da exportação, além disso, há a necessidade de se concentra na qualidade da produção.

Toda a produção de castanha, de Serra do Mel, é processada e comercializada pela unidade, o principal mercado consumidor é a Europa (Suíça, Itália, Austrália, Inglaterra). São os próprios compradores que fiscalizam o trabalho da cooperativa, conforme afirma a entrevistada: "todo ano eles vem aqui, mandam um simples elogio a todos os sócios, certificam-se da qualidade no desenvolvimento do processo produtivo".

Atualmente a cooperativa Já está na $3^{\circ}$ sede, chega a produzir 15 mil $\mathrm{kg}$ por mês, exporta 60 toneladas por safra, é o terceiro projeto com certificado do IBD no Nordeste, primeiro lugar em termos agricultura familiar no Rio Grande do Norte.

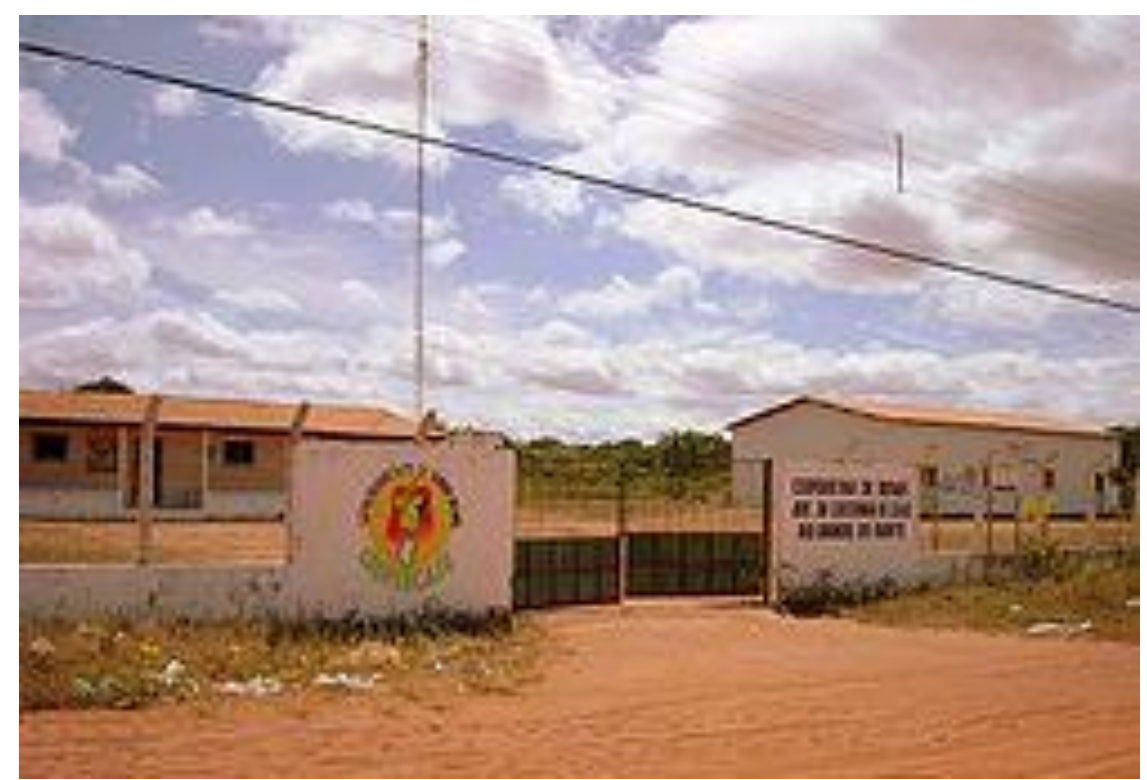

Fotogratia 1

Fonte: jailtonandre.com

Para garantir a pontualidade e a qualidade na entrega de um pedido é feito um rastreamento, previsão de safra de todos os associados, para poder fechar os contratos. Cada associado preenche suas planilhas e leva pra associação onde serão catalogados todos os dados, a partir de então será feito uma previsão de quantidade e prazo de entrega das amêndoas. Há também, treinamento de boas práticas de fabricação, produção, geralmente diferido pela própria cooperativa e seus parceiros.

O trabalho desenvolvido pela COOPERCAJU atinge hoje um nível de organização que possibilitou a certificação em produção orgânica de um grupo de produtores de castanha. Para isto, vem sendo realizado um intenso trabalho de capacitação junto aos agricultores para garantir a implementação de práticas adequadas de conservação do 
solo, incorporação de matéria orgânica, utilização de produtos naturais, entre outras técnicas, visando uma produção sustentável da agricultura em Serra do Mel.

Atualmente o COOPERCAJU também possui o selo do Comércio justo. Essa é uma das certificações em grupo mais importantes para a agricultura familiar, Fair trade, ou de comércio justo e solidário. Essa certificação envolve o desenvolvimento social, econômico e ambiental da produção agrícola.

O consumidor europeu é consciente em relação à Economia Solidária, nesse cenário a cooperativa oferece a castanha orgânica como principal item da pauta exportadora, que além de ser bem aceito no mercado tem valor agregado considerável.

A produção orgânica é muito importante para a inserção do agricultor familiar no mercado. Conforme afirma a gestora, "se não for orgânica, a agricultura familiar não entra nesse mercado competitivo, agressivo. O mercado orgânico paga $30 \%$ a mais do mercado convencional, por ser agricultura familiar inserida no Fair trade, além disso, os compradores europeus são o mais consciente e valorizam o trabalho. Um exemplo, o americano paga $R \$ 9.00$ pelo quilo da amêndoa enquanto que o europeu paga até $R \$$ 26,00 .

A produção orgânica de caju trata-se do modo de produção sem a utilização de adubos químicos ou agrotóxicos, em consórcio com outras culturas, além de aumentar gradativamente a fertilidade do solo. A produção da castanha orgânica requer muitos cuidados com o solo, cultivo do fruto, manejo, colheita e beneficiamento, na cooperativa esses cuidados são de fundamental importância para garantir a qualidade do produto bem como a satisfação do cliente.

A Economia Solidária sempre existiu na unidade, o comércio solidário é um fator de competitividade para a cooperativa, que trabalha com agricultura familiar inserida no Fair trade há mais de uma década, cujos resultados sócio-econômicos são bastante expressivo para a comunidade inserida no processo. Conforme afirma a entrevistada, "a maioria dos nossos clientes são bem antigos, estão conosco há 15 anos, existe uma relação muito próxima e transparente, entre produtor e consumidor. Os nossos compradores não enxergam apenas o produto, mas sim o trabalho. Isso é refletido no momento da negociação, na formação de preço e na produção".

Esse cenário nada mais é do que a confirmação da ação social e solidária existente nas relações comerciais da COOPERCAJU. Ainda segundo a gestora: "Independente do valor do contrato, o comprador antecipa $50 \%$ do valor acordado para cooperativa, fato que garante renda para a família produtora e assegura a qualidade e a pontualidade na entrega do produto". Isso reflete na comunidade como um todo, garantindo o sustento da família, educação dos filhos, qualidade de vida, além da certificação da relação de confiança que existe entre os envolvidos no processo de produção e consumo. Para a entrevistada, "quando se trabalha com comércio solidário se economiza muitas etapas, estreitando o caminho entre produtor e consumidor, isso garante melhor preço e consequentemente, melhor condição de vida para os produtores. Um exemplo disso é o fato do caju ainda está no lote e as famílias já estão usando o dinheiro, 50\% adiantado, para o seu sustento. O processo de beneficiamento é uma a uma, proporcionando qualidade do produto, isso faz diferença na economia solidária”. 
No Brasil, o consumo da castanha de caju ainda é baixo e sazonal, a conscientização sócio-econômica ainda precisa ser melhorada, por isso o principal foco é o mercado externo, consumidor ativo e consciente em relação à agricultura familiar inserida na Economia Solidária.

A industrialização da castanha de caju em unidades familiares é o grande diferencial dos produtores de Serra do Mel em relação aos demais produtores do Nordeste brasileiro. Os produtores desenvolveram uma tecnologia alternativa de sistema de beneficiamento descentralizado de castanha de caju, adaptando a tecnologia industrial para a miniindustria familiar (unidades familiar). Essa tecnologia tem como base unidades familiar de produção de castanha de caju, que garantem um controle da qualidade da amêndoa, apresentando-se como alternativa para a redução dos problemas de quebras de amêndoas inteiras, sem manchas e de coloração clara, e ainda possibilita a inserção dos pequenos agricultores familiares de castanha de caju no mercado internacional. Sendo maior parte do processo de beneficiamento realizado manualmente, uma a uma.

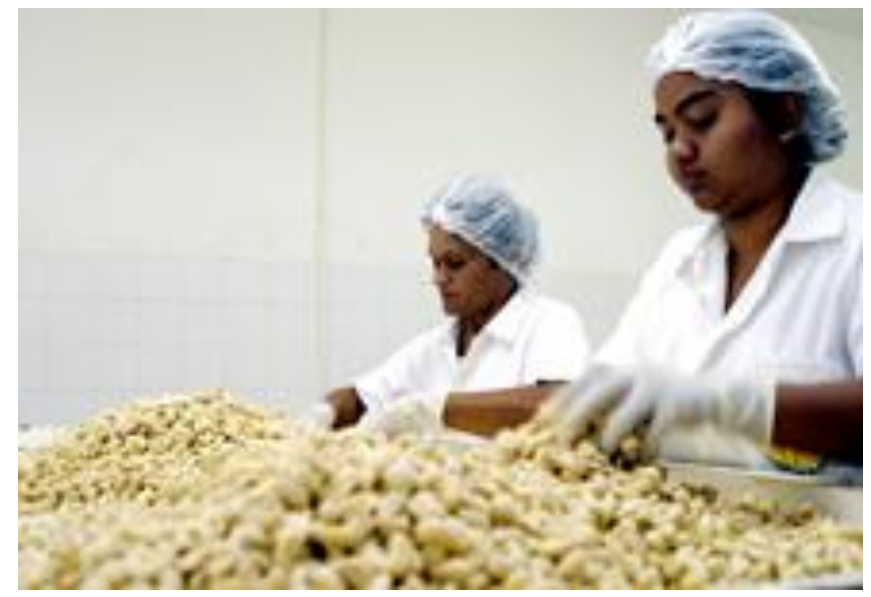

Fotografia 2

Fonte: agenciasebrae.com.br

Ao longo dos 19 anos de atuação da cooperativa, muitos desafios foram superados, especialmente por se tratar de agricultura familiar, questões de beneficiamento, qualidade da amêndoa, tramitem burocráticos para a exportação, legislação, logística, a própria gestão da cooperativa, mas , conforme a firma a gestora da unidade: "essas dificuldades são diminuídas quando se trabalha por um objetivo em comum".

Atualmente a cooperativa possui 106 sócios, a maioria dos cooperados são homens com mais de 45 anos, casados, pais de pelo menos quatro filhos, que segundo dados coletados, todas as crianças frequentam a escola regularmente, além de ajudarem nas atividades domésticas. A maioria dos cooperados não concluiu o Ensino Fundamental, por isso se preocupa com a educação dos filhos.

$\mathrm{Na}$ COOPERCAJU existem três tipos de sócios. O associado fornecedor, aquele que produz, mas não beneficia a castanha; o associado mão-de-obra, aquele que não tem lote, mas beneficia a castanha dos outros associados, e o associado produtor e fornecer de castanha.

O trabalho dos associados é desenvolvido na própria residência, o seu lucro é determinado pela produção cujo valor mínimo chega a $\mathrm{R} \$ 1.000,00$ por associado. Na 
unidade sede da cooperativa é feito seleção, classificação e comercialização da amêndoa.

Cada casa reside pelo menos quatro pessoas, que geralmente trabalham com a cajucultura. No período de entressafra, há estocagem da castanha, além de receberem castanhas de outros municípios. A comunidade pratica a cultura de subsistência, quando tem chuva. Além disso, o município de Serra do Mel é referência, no Estado, na apicultura.

Desde 2006 que a cooperativa está sendo abastecida pelas associações gestoras das mini-fábricas do município de Portalegre e das comunidades de Mirandas, em Caraúbas, e do Córrego, em Apodi. Com o reforço das três minifábricas em funcionamento no Estado, há um volume maior de amêndoas para suprir a escassez que vinha ocorrendo na cooperativa. O projeto da central de comercialização foi desenvolvido pelo Sebrae em parceria com a Fundação Banco do Brasil, com o apoio dos parceiros do Programa de Apoio à Cadeia Produtiva do Caju: Banco do Brasil, Embrapa, Conab, Emparn, Emater-RN, Coopercaju e Telemar (TRIBUNA DO NORTE, 2006).

Essas parcerias são de extrema importância para a concretização do trabalho desenvolvido pelos agricultores familiares, que sozinhos não conseguiriam tanto respaldo, além de garantir o abastecimento da cooperativa gerando trabalho e renda o ano todo.

Quanto aos projetos futuros, a entrevistada afirma que as perspectivas são muitas para implementação de maquinário, da própria estrutura da unidade, bem como desenvolver novas técnicas de aproveitamento do pedúnculo visando novos mercados, pois a amêndoa já estar consolidada no mercado, o desafio agora é buscar novas alternativas de consumo, já que o caju é um produto sazonal, objetivando garantir trabalho o ano todo.

Atualmente a cooperativa desenvolve um trabalho com um grupo de mulheres para aproveitar o pedúnculo, extremamente perecível, no entanto muito rico em vitaminas. Através desse trabalho, as mulheres da comunidade, em parceria com outras entidades da região desenvolvem um trabalho de aproveitamento do pendúnculo, através de cursos de doces, polpa, que Já estão sendo comercializando para a merenda escolar do município, através do Programa Venda Direta. Fato que a gestora da cooperativa considera um avanço.

Ainda segundo a entrevistada, o mercado para os produtos provenientes do pedúnculo do caju é amplo, isso ela enxergar nas feiras internacionais onde pode ser constatada a demanda: "Futuramente existe a intenção de trabalhar o aproveitamento da polpa, desenvolver o caju desidratado, caju passas, hamburgue de caju para casas de alimentos naturais". Mas por ser um produto extremamente perecível, existem várias exigências técnicas, qualificação profissional, dentre outros aspectos que deverão ser superados.

Pensando no futuro da cooperativa, há um trabalho com um grupo de jovens que estão sendo conscientizados em relação à cultura orgânica, trazendo o aprendizado do manejo do cajueiro orgânico para os futuros sócios da cooperativa. 
Todas essas ações garantem respaldo e consolidação do trabalho desenvolvido pela COOPERCAJU que viabiliza a customização e comercialização da castanha proveniente da agricultura familiar, agregando valor ao produto, inserido-o no mercado internacional pelo comércio justo e solidário, onde todos os envolvidos, diretos e indiretos, no processo são beneficiados através das ações socioeconômicas que a cooperativa vivência pelo meio da Economia Solidária.

\section{CONSIDERAÇÕES FINAIS}

Através do presente estudo, pode ser constatado que a Economia Solidária (ES) é uma ação econômica que vem se desenvolvendo no mundo, ao longo dos anos, devido aos problemas causados pelo processo de globalização, internacionalização dos mercados em detrimento das poucas ações voltadas para o social, destinada à população de baixa renda e para o pequeno produtor.

O cenário econômico está deixando de lado um grande contingente de trabalhadores sem qualificação profissional. O mercado caminha para um futuro sem perspectivas de emprego e renda para a grande maioria das pessoas que vivem nas periferias das grandes cidades e no campo, atingindo todos os níveis de idade e sexo populacional. Os postos de trabalhos estão cada vez mais competitivos porque o atual modelo econômico não gera empregos na mesma proporção em que surgem novos trabalhos.

A Economia Solidária surge como alternativa de inserção dessas pessoas no cenário econômico, os resultados são notórios, mesmo que de forma modesta, mas gradativamente os índices de desemprego estão sendo diminuídos no Brasil, graças às ações da ES, principalmente nos Estados do Nordeste, onde historicamente os índices de desemprego e falta de mão-de-obra qualificada imperam.

Isso mostra que quando as ações sociais são levadas a sério podem ser colhidos frutos permanentes pela sociedade. Nota-se, também, que não é só a boa vontade que pode promover essas ações, as diversas esferas, tais como, Governo, Universidades, ONGS, podem fornecer benefícios técnicos, financeiros, viabilizando a promoção da Economia Solidária e Social no Brasil e no mundo.

O cenário atual mostra que deve ser estimulado uma política de emprego, que promova uma maior organização coletiva dos trabalhadores visando o processo de desenvolvimento sócio-econômico igualitário, seja numa esfera micro ou macro as pessoas, as empresas precisam se articular para garantir um crescimento sustentável.

O mercado local precisa despertar para essa nova realidade, o Comércio Justo é o caminho para o futuro das relações comerciais internacionais. O mercado externo já vem se inserindo nesse contexto, objetivando a diminuição da pobreza no mundo e o fortalecimento do desenvolvimento sustentável adquirindo produtos provenientes de estabelecimentos associativos que priorizam a valorização do trabalho.

Nota-se que o Brasil está engatinhando com a Economia Solidária, tem potencial para liderar no mercado através do comércio justo e solidário, graças às novas ações governamentais e aos projetos que estão dando certo. 
A ES é viável para todos, homens, mulheres, jovens, pequenos produtores. É nesse contexto que a agricultura familiar nordestina está se superando ano a ano, onde os pequenos agricultores associados em cooperativas estão se articulando para se manterem no mercado e garantir o desenvolvimento sócio-econômico e qualidade de vida da comunidade inserida no processo. Justos esses cooperados estão descobrindo caminhos mais curtos para diminuir a distância entre produtor e consumidor através de alternativas mais justa e equitativa inserindo a agricultura familiar no comércio justo e solidário.

Na COOPERCAJU, a Economia Solidária se mostrou pertinente, pois a proposta da cooperativa, em si, é voltada para o social, o principal produto é a castanha orgânica, totalmente inserida no comércio justo e solidário.

A Economia Solidária se apresenta como fator determinante para a promoção da competitividade da amêndoa customizada na cooperativa, para o mercado internacional, processada artesanalmente, uma a uma, cujo processo faz diferença para o mercado consumidor, consciente e disposto a pagar mais pelo produto que é desenvolvido pela agricultura familiar através da Economia Solidária, proporcionando o desenvolvimento social e a qualidade de vida da comunidade inserida nesse contexto.

Observou-se também que a COOPERCAJU desenvolve um trabalho de qualidade em relação à customização da castanha através de uma tecnologia alternativa de beneficiamento descentralizado de castanha de caju, as unidades familiares, que garantem um controle de qualidade da amêndoa, e possibilita a inserção do pequeno produtor no mercado internacional.

A cooperativa é atuante no processo de capacitação e inovação voltada para o cultivo e o processamento da castanha, e com a ajuda do Estado a unidade está cada vez mais inserida no mercado internacional, com participações em feiras e eventos internacionais, acessibilidade dos mercados, incentivos governamentais, dentre outros aspectos.

Além disso, a cooperativa valoriza o lugar da mulher, buscando alternativas de inserção das cooperadas através de cursos e treinamentos voltados para o aproveitamento do caju, bem como a orientação dos jovens em relação ao trabalho da COOPERCAJU, visando o futuro da cooperativa.

Apesar das dificuldades enfrentadas pelos associados, ao longo dos 19 anos de vida da cooperativa, a COOPERCAJU vem conseguindo se manter no mercado, fidelizando os seus clientes, altamente exigentes. Tudo isso com produto de qualidade, diferenciado e com valor agregado, através da agricultura familiar inserida no comércio solidário.

Com relação às contribuições, a COOPERATIVA poderia criar parceria com uma universidade local para implementar um projeto de incubação, objetivando o aproveitamento do pedúnculo do caju, onde poderia desenvolver produtos alimentícios provenientes do pedúnculo através de adequação tecnológica, qualificação de mão-deobra, técnicas de manejo e armazenamento do produto, dentre outros.

Levando em consideração a carência do mercado alimentício e terapêutico, de produtos provenientes do caju, seria interessante aproveitar essa oportunidade dando início aos estudos, através de incubação, pois o mercado é promissor e a cooperativa tem 
condições favoráveis para dar início ao projeto. O fato de a cooperativa atuar no mercado internacional viabilizaria a comercialização dos produtos provenientes do pedúnculo, que certamente iria ter consumidor garantido na Europa e em outras partes do mundo, devido a receptividade desses consumidores às novidades mercadológicas, bem como a ausência da fruta, polpa, e sucos de caju nesses mercados.

Durante a realização desse trabalho observou-se que os meios de comunicação precisam difundir essa idéia, Economia Solidária, manter a população consciente dessas medidas alternativas e eficazes ao combate das desigualdades sociais. Além disso, houve uma dificuldade de encontrar material bibliográfico atualizado que demonstrasse as experiências vividas pela agricultura familiar através da Economia Solidária, principalmente no Estado do Rio grande do Norte.

Desse modo, espera-se que o estudo constitua sua contribuição para a difusão da Economia Solidária, bem como afirmação das ações sociais e solidária, desenvolvida, na COOPERCAJU através da agricultura familiar. Além disso, que possa servir de estudos posteriores ligados ao tema. Acredita-se que poderia ser explorado com mais veemência a questão das vantagens que o Estado pode obter promovendo ações para a agricultura familiar voltada para o comércio justo e solidário, créditos de financiamento e políticas de fomento aos empreendimentos de Economia Solidária, e também a implementação tecnológica para viabilizar a inserção dos produtos orgânicos no mercado internacional, essas são as sugestões para novos estudos de pesquisa.

\section{REFERÊNCIAS}

1. FRANÇA FILHO, Geneauto Carvalho et al. (Org). Ação Pública e Economia Solidária: uma perspectiva internacional-Porto Alegre: UFRGS, 2006.

2. KUSTER, Angela; MARTÍ, Jaime Ferré (Org). Agricultura familiar, agroecologia e mercado no Norte e Nordeste do Brasil-Fortaleza: Fundação Konrad Adenauer, DED 2004. Disponível em:

3. < http://www.agroecologia.inf.br/biblioteca/Agricultura\%20Familiar.pdf> Acesso em: 10 Jun. 2010.

4. BOCAYUVA. Pedro Claudio Cunha, VARANDA. Ana Paula de Moura. Tecnologia social, economia solidária e políticas públicas. 1. ed. Rio de Janeiro: 2009.

5. CARBAUGH, Roberto J. Economia Internacional. São Paulo: Thompson, 2004.

6. COSTA, Luiz Gonzaga Araújo. Dados Conjunturais da Castanha-de-Caju: Safra 2009/2010.CONAB/RN, Natal: 2009.

7. DABELLO, Osvaldir, FRANZ, Diane. Cooperativismo-organização social como base do desenvolvimento sustentável da agricultora familiar. Disponível em: <ftp://ftp.sp.gov.br/ftppesca/IIsimcope/oficina_osvaldir_diane.pdf > Acesso em: 2 Jun. 2010.

8. FRANÇA, Lidiane da silva; SILVA; Etevaldo Almeida. Balança comercial do agribusiness agropecuário do Rio Grande do Norte 1998 a 2004. Mossoró: UERN, 2008. 
9. FURTADO, Milton Braga. Síntese da economia brasileira. 7. ed. Rio de Janeiro: LTC, 2000.

10. GONÇALVES, Jackson Eduardo. Economia Solidária: Solução Recente para a Agricultura Familiar. Minas Gerais: 2005. Disponível em <http://www.sober.org.br/palestra/2/881.pdf> Acesso em: 28 Mai. 2010.

11. IRION, João Eduardo. Cooperativismo e economia social. São Paulo: STS, 1997.

12. JORNAL DEFATO. Rn ganha mais duas minifáricas. Disponível em: http://www.defato.com/03_06_2009/estado.php. Acesso em: 11 Nov.2009.

13. KREUTZ, Eneida T. Cooperativismo Passo a Passo. 7. ed. Goiânia: Departamento de Educação Cooperativista, 2004.

14. MAIA, Jayme de Martins. Economia Internacional e Comércio Exterior. 11. ed. São Paulo: Atlas, 2007.

15. OLIVEIRA, Ana Georgina P. Rocha. Diagnóstico da Cadeia Produtiva do Caju na Bahia-Potencial Territorial de Identidade. Semiárido Nordeste II. 10. ed. Rev. Desenbahia, 2009.

16. OLIVEIRA, Elvira Fernandes de Araújo; FILGUEIRA; Maria Conceição Maciel. Primeiros Passos da Iniciação Científica.Mossoró-rn: Fundação Vingt-Un Rosado, 2004.

17. PORTER, Michael E. Vantagens Competitivas: Criando e sustentando um desempenho superior. 31 ${ }^{\mathrm{a}}$ ed. Rio de Janeiro: Campos, 1989.

18. REVISTA SEBRAE AGRONEGÓCIOS. Cajucultura, no Rio Grande do Norte - Mais renda para o produtor. 7. ed. 2007.

19. Disponível em<http://www.agenciasebrae.com.br>. Acesso em: 27 nov.2009.

20. ROCHA, Marília; Agronegócio e indústria impulsionam o crescimento do PIB. Disponível em: <http://www.nominuto.com/noticias/economia/agronegocioe-industria-impulsionam-crescimento-do-pib/25348/> . Acesso em: 29 nov.2009.

21. SANTOS. Sabrina Rodrigues. Cooperativismo e economia solidária. Disponível em:

<www2.oabsp.org.br/...COOPERATIVISMO_ECONOMIA_SOLIDARIA.pd f>. Acesso em: 22 abr.2010.

22. SOUZA, André; CUNHA, Gabriela; DAKUZAKU, Regina (Org.) Uma outra economia é possível: Paul Singer e a Economia Solidária. São Paulo: Editora contexto, 2003.

23. SOUSA, Jânia Maria Pinho. Avaliação do financiamento da agricultura familiar na produção e ocupação de renda. $\mathrm{N}^{\circ} 18$, Série BNB Teses e Dissertações-Fortaleza: Banco do Nordeste do Brasil, 2009.

24. STEDILE, João Pedro. A Questão Agrária no Brasil, o debate na esquerda1960-1980. 2. ed. São Paulo: Expressão Popular, 2005.

25. TAVARES, Edson Diogo. Da Agricultura Moderna à Agroecologia: análise da sustentabilidade de sistema agrícolas familiares. Fortaleza, 1. ed., Banco do Nordeste do Brasil; EMBRAPA: Fortaleza, 2009. 
26. TRIBUNA DO NORTE. RN Começa e Exportar Castanha. Disponível em: http://tribunadonorte.com.br/noticia/rn-comeca-exportar-castanha/5045. Acesso em 11 Nov.2010. 


\title{
APÊNDICE A - QUESTIONÁRIO I
}

DEPARTAMENTO ACADÊMICO DA GESTÃO, SERVIÇOS E COMÉRCIO CURSO SUPERIOR DE TECNOLOGIA EM COMÉRCIO EXTERIOR

\author{
Identificação da Empresa
}

1) Denominação da Empresa:

2) Endereço:

3) Telefone: Celular:

4) Emails:

5) Nome completo do responsável pelas informações:

6) Cargo(s) do responsável(s) pela(s) informação(ões)

7) Grau de escolaridade:

( ) Superior Completo;

( ) Superior Incompleto;

( ) Ensino Médio Completo;

( ) Ensino Médio Incompleto;

( ) Outro.

Qual?

8) Quantos sócios há na cooperativa?

( ) Até 100

( ) de 100 a 200

( ) de 200 a 300

( ) de 300 a 400

( ) Outros 
Qual?

09) Qual o ramo de atuação da cooperativa?

\section{EXECUÇÃO DO TRABALHO}

10) Qual o motivo que os levou a vincular-se à Cooperativa?

( ) falta de oportunidade de trabalho;

( ) remuneração;

( ) identificação com os princípios do cooperativismo;

( ) benefícios;

( ) outros.

Qual?

11) Qual o local de desenvolvimento do trabalho executado pelos cooperados?

( ) na própria cooperativa;

( ) em casa;

( ) numa unidade produtiva da cooperativa;

( ) parte na cooperativa e o restante em casa;

( ) outro

Qual?

12) Como funciona a definição da sua jornada de trabalho?

13) Determinação da renda:

( ) remuneração fixa;

( ) produção;

( ) remuneração fixa + produção;

( ) fixo + produção + beneficiamentos.

( ) outros.

Qual?

Qual?

14) Como funciona o controle de extravio, desperdício e queda da produtividade já que o trabalho não é desenvolvido na cooperativa, e sim na residência de cada cooperado? 
15) Atualmente a unidade opera em sua plena capacidade?

( ) Não. Por quê?

( ) Sim. Por quê?

16) Existe a pretensão de expandir a produção e com isso trazer mais associados à cooperativa?

17) Qual a sua satisfação em relação ao trabalho desenvolvido e o seu retorno financeiro?

( ) Pouco satisfeito;

( ) insatisfeito;

( ) pode melhorar;

( ) satisfeito;

( ) muito satisfeito;

( ) Outro.

Qual?

18) Quais as etapas de produção e customização da amêndoa de castanha de caju realizada na Cooperativa?

19) Há o cultivo de outras culturas, além do caju, no mesmo solo? Qual (s)?

20) A coopercaju beneficia apenas castanha do município de Serrado Mel?

21) Como é desenvolvida a cultura de auto-sustento na comunidade?

( ) cada família cultiva o suficiente para o seu sustento;

( ) cultiva para o seu sustento e para comercializar;

( ) outro

Qual?

22) Quais os produtos derivados do caju, além da amêndoa da castanha, é comercializado? 
23) Toda a safra de cada família cooperada é beneficiada ou há estocagem da castanha?

24) Quais fatores podem gerar perda na produtividade:

( ) fatores climáticos;

( ) pragas;

( ) outro

Qual?

25) Atualmente qual é a dimensão da área cultivada de cajueiro em serra do Mel?

EDUCAÇÃO

26) Existe treinamento na cooperativa?

( ) nunca;

( ) às vezes;

( ) geralmente;

( ) sempre.

27) Os cursos são ofertados por qual instituição?

( ) a própria cooperativa;

( ) O SEBRAE;

( ) outras cooperativas;

( ) outras instituições.

Qual?

28) Quais os tipos de cursos ofertados?

29) Qual a sua finalidade?

30) Existe treinamento oferecido aos cooperados para lidar com a cajucultura?

( ) Técnicas de cultivo;

( ) técnicas de colheita;

( ) aproveitamento de toda a matéria-prima;

( ) Desperdício

( ) estocagem

( ) outras 
Quais?

31) Você concorda que a sociedade local é beneficiada com melhorias sócioeconômicas promovidas pela cooperativa? Quais?

\section{ECONOMIA E COMÉRCIO INTERNACIONAL}

32) Quando se deu o início da execução da economia solidária?

33) Quais os fatores levaram a cooperativa a se envolver com a economia solidária?

34) Qual o impacto da economia solidária nas relações internacionais?

35) Qual o impacto da economia solidária na vida econômica-social dos cooperados?

36) Qual o impacto da economia solidária no contexto produtivo-comercial da Coopercaju?

37) Há quanto tempo a Cooperativa está inserida no comércio exterior?

38) Quais as perceptivas da cooperativa em relação a inserção de novos mercados internacional?

39) Qual a importância das políticas de fomento do governo, tais como financiamentos, feiras, treinamentos para a cooperativa?

40) Qual o volume anual da castanha processado pela unidade?

41) Principais destino da produção?

42) Qual o valor do quilo da castanha já processada?

Orgânica:

Não orgânica:

43) Qual a aceitação da castanha orgânica no mercado externo e interno?

44) Qual o tipo de amêndoa mais apreciada pelo mercado internacional? 
45) O custo de produção é o mesmo? E o processo de beneficiamento da castanha orgânica é o mesmo?

46) Quais as principais exigências para a inserção do produto no mercado internacional?

47) Quais os principais fatores competitivo do produto?

48) Qual o diferencial competitivo da coopercaju em relação as indústria de beneficiamento de castanha instaladas no estado do RN?

49) Como você enxerga a concorrência dos Estados produtores de castanha em relação à produtividade do Rio Grande do Norte?

\section{PERFIL DOS COOPERADOS}

50) Sexo:

( ) masculino;

( ) feminino.

51) Idade:

( ) menos de 15 anos;

( ) de 15 a 20 anos;

( ) de20 a 25anoa;

( ) de 25 a 30 anos;

( ) de 30 a 35 anos;

( ) de 35 a 40 anos;

( ) de 40 a 45 anos;

( ) mais de 45 anos.

52) Estado civil;

( ) Solteiro (a);

( ) Casado (a);

( ) União estável;

( ) divorciado (a);

( ) Viúvo (a);

53) Número de filhos: 
( ) nenhum;

( ) mais de 1 .

Quantos?

54) Todos os filhos freqüentam a escola?

55) Grau de escolaridade:

( ) Ensino médio completo;

( ) Ensino médio incompleto;

( ) Outros

Qual?

56) Tipo de moradia:

( ) casa própria;

( ) casa própria dos pais;

( ) alugada;

( ) alugada pelos pais;

( ) alugada por você;

( ) financiada;

( ) parentes ou amigos;

( ) outros.

Qual?

57)Em média, quantas pessoas residem na mesma casa?

Todas trabalham para a cooperativa? ( ) Sim; ( ) Não.

Se"sim",quantas?

( ) frutas

( ) outra

Qual? 